\title{
Article \\ The Effect of IMC of Golf Product Exhibitions on Customer Behavior and Recommendation Intention
}

\author{
Taeyoung Cho ${ }^{1,+} \mathbb{D}$, Taesoo Cho ${ }^{2,+} \mathbb{D}$ and Hao Zhang ${ }^{3, *} \mathbb{D}$ \\ 1 Department of Hotel Tourism Management, Dongguk University, Gyeongju 38066, Korea; \\ cty0629@dongguk.ac.kr \\ 2 School of Exercise and Sport Science, University of Ulsan, Ulsan 44610, Korea; cts1119@hanmail.net \\ 3 Key Laboratory of Land Surface Pattern and Simulation, Institute of Geographic Sciences and Natural \\ Resources Research, Chinese Academy of Sciences, Beijing 100101, China \\ * Correspondence: zhanghao@igsnrr.ac.cn \\ $\dagger$ The first two authors contributed equally to this work.
}

Citation: Cho, T.; Cho, T.; Zhang, H. The Effect of IMC of Golf Product Exhibitions on Customer Behavior and Recommendation Intention. Tour. Hosp. 2021, 2, 288-301. https:// doi.org/10.3390/tourhosp2030018

Academic Editor: Brian Garrod

Received: 23 April 2021

Accepted: 25 June 2021

Published: 2 July 2021

Publisher's Note: MDPI stays neutral with regard to jurisdictional claims in published maps and institutional affiliations.

Copyright: () 2021 by the authors. Licensee MDPI, Basel, Switzerland. This article is an open access article distributed under the terms and conditions of the Creative Commons Attribution (CC BY) license (https:// creativecommons.org/licenses/by/ $4.0 /)$.

\begin{abstract}
The aim of this study was to present strategic measures for the sustainability of exhibitions and fairs by examining the relationship between integrated marketing communication (IMC) and the customer behavior and recommendation intentions of the participants who attended golf exhibitions and fairs. To achieve this aim, we conducted a literature review of IMC to formulate a hypothesis; next, we administered a questionnaire to 256 participants at the exhibitions and fairs related to golf equipment. The results show that the two-way communication of the exhibition and fair was positive for the customer's continuous purchase intention, purchase behavior, and long-term relationship orientation, and the purchase behavior and long-term relationship orientation had a positive effect on the continuous recommendation intention.
\end{abstract}

Keywords: integrated marketing communication; customer behavior; recommendation intention; golf equipment exhibition and fair

\section{Introduction}

Today, integrated marketing communication (IMC) has become one of the core communication activities of domestic and foreign companies. In particular, there is fierce competition within the sports market, including corporate warfare. Under these conditions, integrated marketing is essential to induce positive consumer behavior and establish effective strategies, demonstrating the importance of communication in effective marketing [1-4]. IMC includes a variety of marketing communication elements, including advertising (AD), public relations (PR), direct marketing (DM), sales promotion (SP), and events. It has been suggested that research should be conducted in various fields, such as business administration, sociology, journalism, advertising, and physical education, to achieve maximum communication effects [5]. To address the gap in the literature regarding IMC at exhibitions and fairs, this study attempts to establish a theoretical foundation for IMC in this context.

As IMCs can be used as a means of strategic enterprise [6], we sought to determine why IMC is used at exhibitions and fairs to market sports products and inform consumers, and how to maintain relationships with businesses and customers gained through these venues. Although IMCs can be used to generate business, it is also important to maintain a lasting relationship between consumers and companies [7]; therefore, an empirical analysis is necessary to clarify the strategic sustainability of exhibitions and fairs. If the marketing is excellent, the visitors at these events may participate continually, which can contribute substantially to regional development and economic growth $[6,8,9]$.

Schultz and Kitchen [10], and Schultz and Schultz [11], argue that companies should continue to accept IMC as being the center of any new management strategy. Sustainability 
is viewed as important, as the results of marketing sustainability to customers are positive. Grove, Carlson, and Dorsch [12], and Font and McCabe [6], state that information should be shared with consumers, but more than product information is necessary to achieve a successful IMC. The essential input of IMC is to create a sense of value for consumers and to conduct consumer-centered business activities; various means should be used to approach consumers. Companies conduct business activities and information activities with consumers in various ways. Regarding the image and information presented about a company (compared to its products), marketing communication activities can be divided into two main categories: above-the-line (ATL) and below-the-line (BTL). While abovethe-line communication activities involve the use of traditional media, such as TV, radio, newspapers and magazines, BTL refers to marketing communication activities other than one-way marketing, which can be divided into DM, SP, PR, event marketing, entertainment marketing, etc., and covers everything except the four major alternatives [13].

As mentioned above, marketing is an integral part of a company's communication with consumers. However, in the case of golf products, Cho [14] and Wells, Burnett, and Moriarty [15] point out that marketing communication must be handled carefully, since there may be a difference between the real value of the information and the value perceived by consumers. Golf equipment enterprises should make efforts to provide service marketing at the point of contact with consumers to maintain customer loyalty; they may also need to adopt new management methods to survive the fierce competition in the modern market. Green [16] supported this advice, saying that service marketing that provides information affects customer behavior; therefore, there is a need to analyze the factors influencing the relationship between information and consumer behavior. In the case of golf equipment exhibitions and fairs, which are the subject of this study, there are two types of booths that provide golf equipment to consumers; that is, a one-way communication booth, and a two-way communication booth. One-way communication booths only provide golf supplies, pamphlets, explanations, and information on exhibits, while two-way communication booths use strategies to provide targeted pamphlets, promote the exhibits, give explanations, and offer advice at the same time. It has been proved that consumers prefer two-way communication that can be experienced in person [17]. Therefore, although the exhibition or fair is served by both types of booth, it is apparent that a strategy focusing on two-way communication should be used.

This study focuses on golf equipment, which may have a different value regarding information and the value that actual consumers feel; this research on sustainability was conducted at the exhibitions and fair sites where consumers and working officials come into contact. Moreover, to identify sustainable strategies for exhibitions and fairs, and propose ultimate corporate management measures, the investigation was conducted through faceto-face meetings with consumers at booths using above-the-line marketing communication and those using below-the-line marketing communication to provide information on golf products.

To achieve this purpose, we first conducted a review of prior research on IMC and customer behavior as a sustainability strategy for exhibitions and fairs. Then, we established hypotheses, and a research model was proposed. The hypotheses were then tested, using confirmatory factor analysis and the results of the structural equation model analysis with AMOS 20.0.

\section{Theoretical Background}

\subsection{IMCS}

Communication is increasingly important because it can enhance the brand value formation of current customers and potential customers, and can include consumer needs that have diversified due to the recent development of IT technology and smartphone market penetration [18]. Consumers are exposed to information that rapidly increases in quantity or quality; it is difficult for them to process all the information they receive, and there is a tendency to simplify this information. However, in daily life, since the 
information is provided without distinguishing the differences between advertising, PR, promotion, and interpersonal sales, this can add to consumer confusion, so it is important to communicate with them directly [19]. Joyner, Lackey, and Bricker [20] also agreed on the importance of IMCs, saying that enhancing quality partnerships between consumers and businesses leads to continuous consumer participation, so businesses should be careful to choose the right method of mutual communication.

This study is conducted regarding the use of IMC, as it is more strategic than other marketing promotions [18]. By comparing, evaluating, and utilizing the strategic roles of various communication methods, such as advertising, DM, SP, and PR, to enhance the added value of overall marketing communication, it was found that IMC also has a high value [21]. Accurate information delivery by service providers affects customer take-up, and proper communication with consumers has become a way to drive customer responses, proving the importance of IMC [22]. Consumers and companies with already cultivated relationships have enjoyed continuous economic growth and improved income levels, and play an important role in sports product purchases and quantitative growth $[3,23]$. Therefore, based on the prior theory, it is apparent that it is necessary to identify the factors that lead to consumers' continuous positive behavior regarding the sub-factors of the IMC in exhibitions and fairs.

This relationship with consumers plays a particularly vital role, where sports product information and services are provided; Kliatchko [2] emphasized the importance of IMC in forming a favorable relationship between businesses and consumers, and establishing a closer relationship quickly.

Concerning the importance of marketing communication, Kotler [24] stated that, because it is an essential means of generating responses and stimulating consumers in the corporate target market, it is necessary to help consumers receive, interpret, and understand the messages that the company provides, so as to translate them into positive customer behavior. Schmitt [25] also argues that consumers prefer companies and brands that create positive emotions and avoid companies and brands perceived as bad; to send a consistent positive message, it is important to integrate marketing communication.

To summarize these prior studies, companies believe that successful marketing communication will be established if they can create a favorable or unique image of the brand through marketing activities, although there may be differences in the types of experiences and activities that consumers participate in through various events [26,27]. In addition, Ehrenberg, Barnard, Kennedy \& Bloom [28] emphasized the importance of below-theline communication to customer behavior. Wilmshurst [13] also said that above-the-line communication focuses on improving relationships between companies and advertisers, rather than on relationships with consumers, which can be a risk. Therefore, analysis of the relationship between IMC and customer behavior will provide the data needed to understand the strategic sustainability of exhibitions and fairs.

\subsection{Customer Behavior and Recommendation Intention}

Ganesan [29], Shen, Richards, and Liu [30], and Carrington, Neville, and Whitwell [31] indicated that customer behavior includes factors such as consumer attitudes, purchase intention, and the hope of creating a lasting relationship. This study refers to the behavior and intention, the fact that consumers want to purchase items, based on the evaluation of perceived products through marketing communication activities at exhibitions and fairs. Schmitt [27] and Brakus et al. [26] also argued that a company's communication activities may be different because consumers participate in exhibitions and fairs with different forms of participation and of experiences offered, as well as degrees of awareness, but this is also affected by communication activities. Halbusi et al. [32] also indicate that consumers can develop favorable perceptions of products and brands through companies' communication experiences, and form a unique and differentiated image for a company, product, and brand. The theory of Davis, Dunn, and Aaker [33] states that factors such as consumers' purchase intentions, behaviors, and long-term relationships can represent customer behav- 
ior in classifying the relationship between companies and consumers. Therefore, in this study, IMC is defined as including the customer's purchase behavior, purchase intention, long-term relationship formation, and recommendation intention. Understanding these customer behaviors can help identify necessary strategies to encourage continued participation by consumers, and to confirm the sustainability of exhibitions and fairs. In this study, purchase intention is defined as the intention to purchase products at a golf exhibition held in the future, and purchase behavior is defined as the willingness to purchase products at the golf exhibition held in the present.

\subsection{Recommendation Intention}

Recommendation intention can be defined as a thought or plan to communicate positive or negative information, which is based on personal feeling, by sharing something with family, friends and other people around [34]. Recommendation intention acts as a source of information, and is a factor that consumers consider when purchasing a product or service. This information, in particular, can be an important factor in the success of product sellers [35]. In addition, it has also been found that recommended information has the most influential effect on reducing the perceived risk in purchasing situations [36]. Therefore, in this study, it can be confirmed that this is an important factor in utilizing it as a sustainable strategy for golf equipment exhibitions and fairs.

\subsection{Research Hypotheses}

The hypotheses in this study are centered on the preceding theories and research. In particular, this study attempted to analyze the relationships affecting consumer behavior, focusing on integrated marketing communication, which is a sustainable strategy for golf equipment exhibitions and fairs. The specific hypothesis settings are as follows.

First, for above-the-line and below-the-line integrated marketing communication, Sherman, Mathur, and Smith [37] argued that if the company provides proper communication to give the information that consumers want, there will be a positive effect on the various responses that consumers have [38]. Boulding, Staelin, and Zethaml [39] state that customers with a positive attitude through IMC may affect their repurchase, reuse, and word of mouth. Madhavaram et al. [3] reported that IMC with consumers affects consumer behavior and long-term relationships. Therefore, it is confirmed that the hypothesis of the relationship with the consumer, purchase intention, and purchase behavior can be established in integrated marketing communication. In addition, Cristobal-Fransi et al. [7] describe the role of integrated marketing in driving consumers' purchase intention and behavior, while Duncan [40] stated that long-term relationships with customers require a focus on the process of integrated marketing. A related study by Kim and Cho [41] supports the hypothesis, set in this study as meaningful, that IMC can develop into a long-term relationship through customer-oriented and mutual interaction. Therefore, a theoretical relationship was established to analyze the relationship between IMC and customer behavior. In the hypothetical relationship analyzed in this study, it can be predicted that above-the-line and below-the-line IMC have a relationship with consumers' behavior. Moreover, the need for integrated marketing-related research is supported to operate continuous exhibitions and fairs promoting golf equipment. Hypotheses 1 and 2 were established based on these theories.

Second, Volos [42], and Lawler, Thye, and Yoon [43], argued that IMC environmental conditions can affect consumers' experiences. Davis et al. [34] found that customer behavior is composed of purchase intention and action, as well as a long-term relationship, and understanding how the consumer's continuous behavior interacts with their relationship with the brand leads to positive results. In conclusion, a relationship is established so that consumers' experiences can be recommended to others. Additional studies have shown that consumers' purchase intention and behavior, and long-term relationships, are the precedence factors that can be recommended to other consumers in the future $[26,31,32]$. Therefore, the analysis of the relationship between customer response and recommendation 
intention, regarding sustainability strategies for exhibitions and fairs in this study, is supported by prior research. Based on previous studies, Hypothesis 3 was also established in this study.

Hypothesis 1 (H1). Above-the-line communication services affect continuous customer behavior.

Hypothesis 1-1. Above-the-line communication services affect purchase intention.

Hypothesis 1-2. Above-the-line communication services affect purchase behavior.

Hypothesis 1-3. Above-the-line communication services affect long-term relationships.

Hypothesis 2 (H2). Below-the-line communication services affect continuous customer behavior.

Hypothesis 2-1. Below-the-line communication services affect purchase intention.

Hypothesis 2-2. Below-the-line communication services affect purchase behavior.

Hypothesis 2-3. Below-the-line communication services affect long-term relationships.

Hypothesis 3 (H3). Customer behavior affects the continued recommendation intention.

Hypothesis 3-1. Purchase intention affects continuous recommendation intention.

Hypothesis 3-2. Purchase behavior affects continuous recommendation intention.

Hypothesis 3-3. Long-term relationships affect continuous recommendation intention.

The research model is shown in Figure 1 as follows.

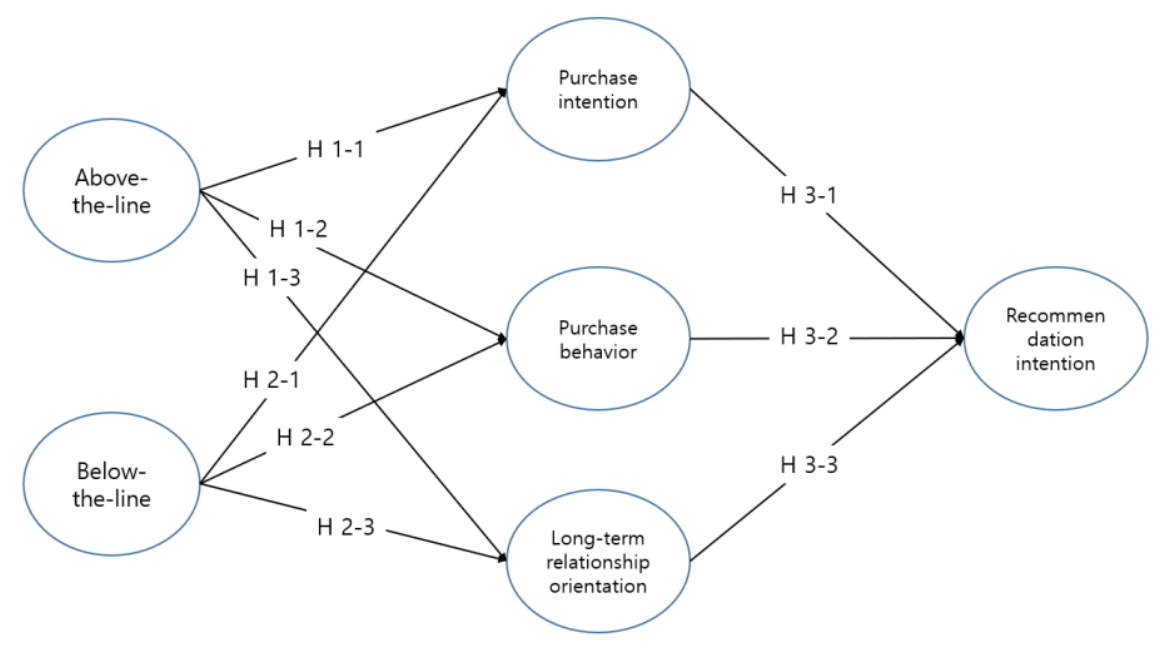

Figure 1. The proposed model of structural relationships.

\section{Research Method}

\subsection{Research Object Selection and Sampling}

To confirm the relationship between integrated communication and consumer response, we distributed and collected questionnaires at golf equipment exhibitions and fairs, where products can be introduced and information can be shared. The golf equipment exhibition and fair are held approximately 10 times per year, and it has the advantage of providing information about a new product. Moreover, since it is operated as an exhibition that mainly launches new products, it is difficult to conduct research through 
other sales channels or with customers as the object. As inclusion criteria, this study targeted customers who were (1) repeat visitors (at least three times per year) at the golf equipment fair and (2) play golf twice a week. One-time participants were excluded from this research because, since the golf equipment exhibitions and fairs operate continuously, those customers did not meet the purposes of the study. Finally, 256 participants, selected using a simple random sampling method, who met the inclusion criteria and completed the questionnaires, were used in the study. Samples were selected for visitors who agreed to participate in the research after explaining the purpose of this study, and while the golf equipment exhibition and viewings were ending, three researchers and investigators directly distributed and retrieved the questionnaire at the exit, through prior consultation with the representatives of the golf equipment exhibition and fair.

\subsection{Measurement of Variables}

Contents related to marketing communication are divided into above-the-line marketing (four questions) and below-the-line marketing (four questions) answered using a five-point Likert scale. The contents were based on the marketing communication suggested by Kotler [44], those items used by Kotler's [25] marketing communication tools, and other prior studies $[5,45,46]$.

The measurement of customer behavioral intention was used in the research of Ganesan [30], based on the questionnaire used by Schmitt [28] and Brakus et al. [27]. This measurement is divided into purchase intention (four questions), purchase behavior (four questions), long-term relationship orientation (four questions), and recommendation intention (four questions); items are answered using a five-point Likert scale.

\subsection{Data Processing Method}

First, data were processed using frequency analysis for the general characteristics of the study subjects, and Cronbach's $\alpha$ test for reliability. Second, correlation analysis was performed to examine the degree of relationship between the variables. Third, hypothesis verification was employed, using AMOS 20.0 to conduct confirmatory factor analysis (CFA) and structural equation model analysis (SEM); the statistical significance level was set at $p<0.05$.

\section{Results}

\subsection{Demographic Characteristics}

The frequency analysis was carried out to identify demographic characteristics, and the result is shown in Table 1. According to the survey, $52.33 \%$ of men answered, which is higher than of women. The other demographic characteristics that account for the highest percentage are as follows; the age group was in their $40 \mathrm{~s}(50.8 \%)$; regarding their occupation, 91 people (35.5\%) were self-employed, and 138 people $(53.9 \%)$ had a university degree. As for monthly income, 103 people $(40.2 \%)$ had a monthly income of less than 3 to 4 million won in the Korean currency unit (KRW).

\subsection{Reliability and Validity of Measurement Tools}

Confirmatory factor analysis was conducted to verify the reliability and validity of the measurement tool. The results of the confirmatory factor analysis were shown in Table 2. Confirmative factor analysis was also conducted to identify $\chi 2$, df, CFI, TLI, and RMSEA.

The results showed that $\chi 2=422.380, \mathrm{df}=232, \mathrm{CFI}=0.950, \mathrm{TLI}=0.941$, RMSEA $=0.057$, and $p<0.001$, indicating a desirable level of fitness. As for the goodness-of-fit criterion, the CFI and TLI are larger than 0.90, and the adoption criterion of RMSEA is less than 0.08 , showing a good fit, so the results of this study are confirmed to be suitable. In addition, to confirm convergent validity, the t-value, average variance extracted (AVE), and concept reliability of the factor load for the final extracted items and constituent factors were verified. Bagozzi and Yi [47] pointed out that high reliability is shown when the concept reliability value is larger than 0.6 and the AVE value is larger than 0.5 , so it can be 
confirmed that there is no problem in using the structural equation model, which was the main purpose of this study.

Table 1. Demographic characteristics of respondents.

\begin{tabular}{|c|c|c|c|}
\hline \multicolumn{2}{|c|}{ Characteristics } & \multirow{3}{*}{$\begin{array}{c}\text { Frequency } \\
145 \\
111\end{array}$} & \multirow{3}{*}{$\begin{array}{c}\text { Percent (\%) } \\
52.33 \\
47.7\end{array}$} \\
\hline & Male & & \\
\hline Gender & Female & & \\
\hline \multirow{5}{*}{ Age } & $20 \mathrm{~s}$ & 34 & 13.3 \\
\hline & $30 \mathrm{~s}$ & 64 & 25.0 \\
\hline & $40 \mathrm{~s}$ & 130 & 50.8 \\
\hline & $50 \mathrm{~s}$ & 22 & 8.6 \\
\hline & $\geq 60 \mathrm{~s}$ & 6 & 2.3 \\
\hline \multirow{6}{*}{ Occupation } & Student & 6 & 2.3 \\
\hline & Worker & 72 & 28.1 \\
\hline & Self-employment & 91 & 35.5 \\
\hline & Professional & 53 & 20.7 \\
\hline & Housewife & 26 & 10.2 \\
\hline & Others & 8 & 3.1 \\
\hline \multirow{4}{*}{ Education level } & High school & 36 & 14.1 \\
\hline & Junior college & 42 & 16.4 \\
\hline & Bachelor's degree & 138 & 53.9 \\
\hline & Above a Master's degree & 40 & 15.6 \\
\hline \multirow{4}{*}{ Monthly income } & Less than 2 million (KRW) & 34 & 13.3 \\
\hline & 2-3 million (KRW) & 35 & 13.7 \\
\hline & 3-4 million (KRW) & 103 & 40.2 \\
\hline & Above 5 million (KRW) & 84 & 32.8 \\
\hline & Total & 256 & 100.0 \\
\hline
\end{tabular}

Table 2. Result of confirmatory factor analysis.

\begin{tabular}{|c|c|c|c|c|c|c|}
\hline & ITEM & Estimate & SE & $\mathbf{t}$ & $\begin{array}{l}\text { Concept } \\
\text { Reliability }\end{array}$ & AVE \\
\hline \multirow{4}{*}{ Above-the-line } & $\begin{array}{l}\text { Product (a) information is } \\
\text { delivered accurately }\end{array}$ & 1 & 0.689 & & \multirow{4}{*}{0.870} & \multirow{4}{*}{0.677} \\
\hline & Proper spatial arrangement is in place & 1.084 & 0.756 & $10.485^{* * *}$ & & \\
\hline & Product information is easy to understand & 1.218 & 0.832 & $11.218^{* * *}$ & & \\
\hline & $\begin{array}{l}\text { You can check the information about the } \\
\text { product comfortably }\end{array}$ & 1.19 & 0.735 & $10.335^{* * *}$ & & \\
\hline \multirow{4}{*}{ Below-the-line } & $\begin{array}{l}\text { Communicating with customers in a soft tone } \\
\text { about product (a) }\end{array}$ & 1 & 0.715 & & \multirow{4}{*}{0.833} & \multirow{4}{*}{0.644} \\
\hline & Showing eye-catching material & 1.066 & 0.872 & $13.027^{* * *}$ & & \\
\hline & $\begin{array}{l}\text { Communicating from the customer's } \\
\text { point of view }\end{array}$ & 0.904 & 0.795 & $12.011^{* * *}$ & & \\
\hline & $\begin{array}{l}\text { Communicate with customers using clear } \\
\text { pronunciation }\end{array}$ & 0.959 & 0.711 & $10.786^{* * *}$ & & \\
\hline \multirow{4}{*}{ Purchase intention } & $\begin{array}{c}\text { I'd like to purchase this fair product as } \\
\text { described (a) }\end{array}$ & 1 & 0.765 & & \multirow{4}{*}{0.849} & \multirow{4}{*}{0.654} \\
\hline & $\begin{array}{l}\text { I will continue to use this fair product that is } \\
\text { described in the future }\end{array}$ & 0.978 & 0.774 & $12.513^{* * *}$ & & \\
\hline & $\begin{array}{l}\text { I will purchase this fair product even if there } \\
\text { are other products }\end{array}$ & 1.204 & 0.864 & $14.046^{* * *}$ & & \\
\hline & I will induce others to buy this fair product & 1.06 & 0.794 & $12.873^{* * *}$ & & \\
\hline \multirow{4}{*}{ Purchase behavior } & I will purchase this fair product (a) & 1 & 0.818 & & \multirow{4}{*}{0.821} & \multirow{4}{*}{0.628} \\
\hline & I will purchase this fair product again & 0.891 & 0.746 & $13.172^{* * *}$ & & \\
\hline & $\begin{array}{l}\text { I will buy this fair product even if } \\
\text { it is expensive }\end{array}$ & 1.001 & 0.808 & $14.662^{* * *}$ & & \\
\hline & I will continue to visit this fair & 0.956 & 0.851 & $15.742^{* * *}$ & & \\
\hline
\end{tabular}


Table 2. Cont.

\begin{tabular}{|c|c|c|c|c|c|c|}
\hline & ITEM & Estimate & SE & $\mathbf{t}$ & $\begin{array}{l}\text { Concept } \\
\text { Reliability }\end{array}$ & AVE \\
\hline \multirow{4}{*}{$\begin{array}{l}\text { Long-term } \\
\text { Relationship } \\
\text { Orientation }\end{array}$} & This fair product (a) will continue to run well & 1 & 0.691 & & \multirow{4}{*}{0.862} & \multirow{4}{*}{0.660} \\
\hline & $\begin{array}{l}\text { I think it is good for me to use this fair } \\
\text { product }\end{array}$ & 1.027 & 0.782 & $11.245^{* * *}$ & & \\
\hline & Using this fair product is important & 1.166 & 0.843 & $11.975^{* * *}$ & & \\
\hline & $\begin{array}{l}\text { Using this fair product has many } \\
\text { benefits for me }\end{array}$ & 1.225 & 0.798 & $11.439 * * *$ & & \\
\hline \multirow{4}{*}{$\begin{array}{l}\text { Recommendation } \\
\text { Intention }\end{array}$} & I will promote this fair product (a) & 1 & 0.842 & & \multirow{4}{*}{0.829} & \multirow{4}{*}{0.632} \\
\hline & I will promote this fair product & 1.071 & 0.910 & $18.717^{* * *}$ & & \\
\hline & I will actively recommend this fair product & 1.039 & 0.869 & $17.463^{* * *}$ & & \\
\hline & I will recommend this fair product positively & 0.955 & 0.793 & $15.212 * * *$ & & \\
\hline
\end{tabular}

Note: (a) = fixed to 1 in analysis, ${ }^{* * *} p<0.001$.

\subsection{Correlation Analysis}

Correlation analysis is also a prerequisite for any analysis, as is presenting a general outline of variables [48] by defining the relationships between the relevant factors (subfactors) used in all research hypotheses, before conducting hypothesis testing. In this study, Pearson's correlation analysis was conducted between variables before verifying the research hypotheses, and the results are shown in Table 3. As a result of the correlation analysis, the correlation coefficient was less than 0.08 , which means there is no multicollinearity problem. In general, if the $p$-value is less than 0.01 , it can be judged to be a very strong level of confidence [49]. In general, a correlation coefficient value of less than 0.2-0.4 is interpreted as low correlation, and less than $0.4-0.6$ as moderate correlation. According to the analysis, purchase behavior and long-term orientation showed the highest correlation, with 0.594, while above-the-line and purchase intention showed the lowest correlation, with 0.242 .

Table 3. The correlation matrix of the measurement model.

\begin{tabular}{ccccccc}
\hline Cronbach's $\alpha$ & Factor & $\mathbf{1}$ & $\mathbf{2}$ & $\mathbf{3}$ & $\mathbf{4}$ & $\mathbf{5}$ \\
\hline 0.840 & Above-the-line & 1 & & & \\
0.849 & Below-the-line & $0.470^{* * *}$ & 1 & & & \\
0.878 & Purchase intention & $0.242^{* * *}$ & $0.324^{* * *}$ & 1 & & \\
0.914 & Purchase behavior & $0.297^{* * *}$ & $0.359^{* * *}$ & $0.319^{* * *}$ & 1 & \\
0.880 & Long-term relationship orientation & $0.416^{* * *}$ & $0.548^{* * *}$ & $0.534^{* * *}$ & $0.594^{* * *}$ & 1 \\
0.869 & Recommendation Intention & $0.276^{* * *}$ & $0.313^{* * *}$ & $0.207^{* * *}$ & $0.558^{* * *}$ & $0.448^{* * *}$ \\
\hline
\end{tabular}

\subsection{Goodness-of-Fit of the Research Model}

The results of the goodness-of-fit and path models of the study model showed that the parameters of the structural model were at maximum likelihood (ML), and the results of goodness-of-fit tests are shown in Table 4; the CFI was 0.946 (>0.90), TLI was $0.937(>0.90)$, and RMSEA was $0.059(<0.08)$, which indicated that the study model was suitable.

Table 4. The goodness of fit for the structural equation model.

\begin{tabular}{cccccc}
\hline $\begin{array}{c}\text { Goodness of } \\
\text { Fit Standard }\end{array}$ & $\times \mathbf{2}$ & df & $\begin{array}{c}\text { CFI } \\
(>\mathbf{0 . 9 0 )}\end{array}$ & $\begin{array}{c}\text { TLI } \\
(>\mathbf{0 . 9 0 )}\end{array}$ & $\begin{array}{c}\text { RMSEA } \\
(<\mathbf{0 . 0 8})\end{array}$ \\
\hline Fit index & 444.665 & 237 & 0.946 & 0.937 & 0.059 \\
\hline
\end{tabular}

\subsection{Hypothesis Verification}

Based on the research model, a structural equation model analysis was conducted to verify the hypothesis, and the results are shown in Table 5 and Figure 2. 
Table 5. Verification result of all hypotheses proposed in this study.

\begin{tabular}{|c|c|c|c|c|c|c|c|c|}
\hline \multicolumn{2}{|c|}{ Hypothesis } & \multicolumn{3}{|c|}{ Pathway } & \multirow{2}{*}{$\begin{array}{l}\text { Estimate } \\
0.102\end{array}$} & \multirow{2}{*}{$\begin{array}{c}\text { SE } \\
0.093\end{array}$} & \multirow{2}{*}{$\begin{array}{c}\text { CR } \\
1.099\end{array}$} & \multirow{2}{*}{$\begin{array}{c}\text { Support/Not } \\
\text { Not Supported }\end{array}$} \\
\hline \multirow{4}{*}{ Hypothesis 1} & 1 & & & Purchase intention & & & & \\
\hline & 2 & Above-the-lineCommunication & $\rightarrow$ & Purchase behavior & 0.036 & 0.092 & 0.388 & Not Supported \\
\hline & 3 & & & Long-term Relationship Orientation & 0.039 & 0.085 & 0.453 & Not Supported \\
\hline & 1 & & & Purchase intention & 0.624 & 0.095 & $6.555^{* * *}$ & Supported \\
\hline \multirow[t]{2}{*}{ Hypothesis 2} & 2 & Below-the-lineCommunication & $\rightarrow$ & Purchase behavior & 0.383 & 0.072 & $5.316^{* * *}$ & Supported \\
\hline & 3 & & & Long-term Relationship Orientation & 0.257 & 0.064 & $3.999 * * *$ & Supported \\
\hline \multirow{3}{*}{ Hypothesis 3} & 1 & Purchase intention & & & 0.091 & 0.070 & 1.307 & Not Supported \\
\hline & 2 & Purchase behavior & $\rightarrow$ & Recommendation Intention & 0.402 & 0.065 & $6.229 * * *$ & Supported \\
\hline & 3 & Long-term Relationship Orientation & & & 0.235 & 0.070 & $3.343 * * *$ & Supported \\
\hline
\end{tabular}

$* * * p<0.001$

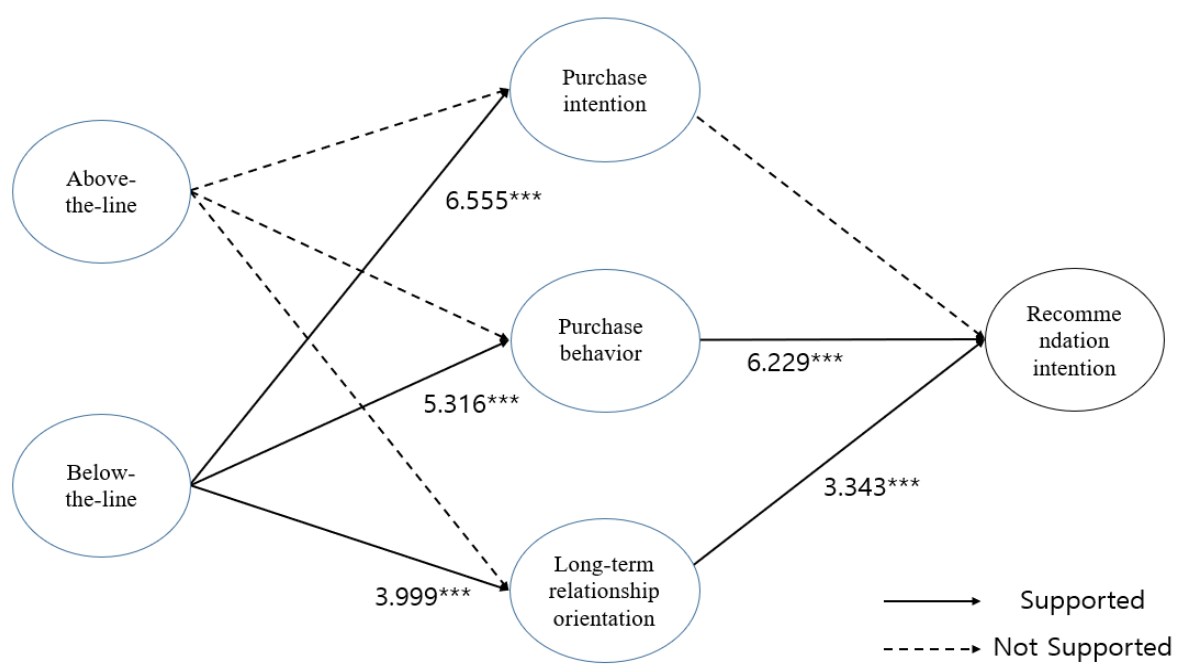

Figure 2. Results of the structural equation model. ${ }^{* * *} p<0.001$.

The verification results for Hypothesis 1 are as follows. In Hypothesis 1-1, abovethe-line communication for continuous purchase intention with the path coefficient value of 0.102, t-value (CR) was $1.099(p>0.05)$, and Hypothesis 1-2 for continuous purchase behavior with a path coefficient value of 0.036 , the t-value (CR) was $0.388(p>0.05)$ as well as in Hypothesis 1-3, where the long-term relationship orientation with the path coefficient value was 0.039 , and $t$-value (CR) was $0.453(p>0.05)$, showing it was not statistically significant. This means that information provided through above-the-line marketing cannot influence customers' purchase intentions, purchase behavior, or long-term relationship orientation. Therefore, it is apparent that the provision of product information in abovethe-line marketing at golf equipment exhibitions and fairs should be avoided.

The results of the verification for Hypothesis 2 are as follows: the below-the-line communication of Hypothesis 2-1 was found to have a significant positive (+) effect $(p<0.001)$ with a path coefficient value of 0.624 and a t-value (CR) of $6.555(p<0.001)$ on the continuous purchase intention. The below-the-line communication of Hypothesis 2-2 also showed a significant positive $(+)$ effect $(p<0.001)$ on continuous purchasing behavior, with a path coefficient value of 0.383 and a t-value $(C R)$ of $5.316(p<0.001)$. The below-theline communication of Hypothesis 2-3 was found to have a significant positive (+) effect $(p<0.001)$ on the continuous long-term relationship orientation, with a path coefficient value of 0.257 and a t-value (CR) of $3.999(p<0.001)$. These results can be interpreted as an attempt to obtain information about the product through below-the-line communication, as emphasized in linear studies. Therefore, below-the-line communication should be actively used as a sustainable strategy for golf equipment exhibitions and fairs.

The verification results of Hypothesis 3 are as follows: the purchase behavior of Hypothesis 3-1 on continuous recommendation intention was statistically insignificant, with a path coefficient value of 0.091 and a t-value (CR) of $1.307(p>0.05)$. The purchase behavior of Hypothesis 3-2 was found to have a significant positive (+) effect on continuous recommendation intention $(p<0.001)$, with a path coefficient value of 0.402 and a $t$-value 
(CR) of $6.229(p<0.001)$. The long-term relationship orientation of Hypothesis 3-3 and the path coefficient of recommendation intention were 0.235 , and the $t$-value (CR) was 3.343 $(p<0.001)$, showing a positive $(+)$ effect $(p<0.001)$. These results can be interpreted as describing the consumers who participate in golf equipment exhibitions and fairs, those who, with actual purchase behavior and long-term relationships, are more willing to recommend items than those who have purchase intention. Therefore, as a sustainable strategy for golf equipment exhibitions and fairs, it is necessary to increase the recommendation intention of potential consumers by trying to maintain a long-term relationship with purchase behavior through below-the-line communication with consumers.

\section{Conclusions}

\subsection{Discussion}

First, in the sub-factors of IMC in this study, the influence relationship on continuous customer behavior in below-the-line communication was positive for purchase intention, purchase behavior, long-term relationship orientation, and recommendation intention $(p<0.001)$. McGrath [50] and Krizanovaet et al. [51] confirmed that when IMC is used in the continuous strategies of consumers and companies, it creates a lasting relationship according to the characteristics of consumers who want to find various pieces of information about the brand. This study can also be interpreted in the same way, and the belowthe-line communication of golf equipment exhibitions and fairs leads to the continuous participation of customers and is positive for purchase behavior and purchase intention. This can be a useful strategy for a company, and can present sustainable possibilities. The company must serve as an information provider for products, one that continuously provides communication to consumers and satisfies their basic needs. Furthermore, it has been proven that marketing that creates a lasting relationship with consumers and brands is a below-the-line communication of companies; Luck and Moffat [52] and Mulhern [53] supported that using this form of marketing is a successful sustainability strategy.

In summary, recently, due to environmental changes in the consumption market and the diversity of consumer needs, consumers want to acquire product information through direct participation and experience, rather than through one-way advertisements provided by companies [54,55]. It was confirmed that it is more advantageous for a company to have a continuous operation using below-the-line marketing communication than to rely on above-the-line marketing to maintain relationships with consumers, highlighting the meaningfulness of the results of this study. In particular, in the case of golf equipment, the golf exhibition has the advantage of minimizing the error of purchasing a product that does not fit one's needs, through the exhibiting and experience of new products. Therefore, if other companies hold exhibition fairs, this should make it possible for consumers to access the product information or product experience.

Second, Ladhari [56] argued that service quality stimulates customer sentiment, and helps them form a relationship. Jaiswal and Niraj [57] also stated that, if a service provider plays a satisfactory role, consumers will tend to recommend the provider and create a lasting relationship. According to these studies, the sustainability strategy of golf equipment exhibitions and fairs relies on establishing a lasting relationship through communication with consumers. Golf equipment exhibitions and fairs are highly valuable places to attract consumers' positive participation. However, this study also proves that it is necessary to use below-the-line marketing to enhance communication with consumers, rather than marketing that provides one-sided information designed only to boost the company's profits.

Consequentially, this study found that, when launching new products or services on the market, the company's decision whether or not to prioritize communication activities with consumers in various forms has determined the success of the company's marketing. It has been confirmed in this study that efforts should be made to conduct continuous marketing communications as part of their strategy, involving the operation of golf equipment exhibitions and fairs, and companies should use below-the-line communication in provid- 
ing a diversity of information, allowing consumers to take an active role in communication and promotion. This recommendation is similar to that of Schultz [58,59], stating that these efforts will be better perceived by consumers and allow for voluntary communication.

Therefore, for a company involved in golf equipment exhibitions and fairs, the theories and results presented in this study should be used to ensure customers' continuous participation in communicating with the company and interacting with their products. Integrated communication is a prerequisite that can determine a company's gain or loss, and more efforts should be made to maintain continuous relationships with consumers at golf equipment exhibitions and fairs for successful corporate management.

\subsection{Theoretical Implications of Research Results}

This study analyzed the relationship between IMC and customer behavior to enhance companies' strategic sustainability through golf equipment exhibitions and fairs. Based on the study results, the theoretical implications are as follows. First, in this study, the research involved customers and companies that continuously participate in golf equipment exhibitions and fairs, which is generally different from previous research that focuses on one-time participants. Therefore, this study makes a meaningful contribution to the literature by establishing a theory for the sustainable management of golf equipment exhibitions and fairs, and their benefits to customers and companies. Second, the positive results of below-the-line communication on purchase intention, purchase behavior, and long-term relationship orientation have proved that below-the-line communication is more important than above-the-line communication. These results are similar to previous findings, but we have used a theoretical basis to demonstrate how they apply to the operation of golf equipment exhibitions and fairs. Third, as a result of proposing an IMC research model for the operation of golf equipment exhibitions and fairs, we proved that the IMC theory can be applied to various aspects of business and marketing. Fourth, due to the nature of golf equipment exhibitions and fairs, the event is designed for consumers to acquire information and experience new products; in particular, providing customer response services through below-the-line communication with customers is a factor in successful hosting. Therefore, it is necessary to actively introduce below-the-line communication in customer relationships in the operation of other product exhibitions and expositions.

\subsection{Practical Implications of Research Results}

The practical implications of this study are as follows. First, the relationship between above-the-line communication and the operation of golf equipment exhibitions and fairs was not supported. The characteristics of golf equipment exhibitions and fairs are supported by the direct participation of consumers. Therefore, to achieve the successful operation of exhibitions, it is necessary to enable below-the-line communication with consumers face to face. Second, golf equipment exhibitions and fairs provide sufficient services to attract consumers' continuous participation. However, the relationship between purchase intention and recommendation intention is not supported. If a method such as a questionnaire or an interview is employed, that can be used to investigate consumers' perceptions before participating in golf equipment exhibitions and fairs, it can be used to enhance meaningful, sustainable relationships and lead to opportunities for enhancing consumers' purchasing behavior and long-term relationship orientation. Third, it has been confirmed that the theory of integrated marketing communication can be used as a continuous strategic method for golfing goods exhibitions and fairs, and the characteristics of two-way communication between service providers and customers should be considered in order to increase continuous customer behavior. This will act as an important means to achieve the purpose of a golf equipment exhibition, as well as other types of company exhibition. Fourth, due to the nature of golf equipment exhibitions and fairs, it should be structured so that users can acquire information and experience new products. In particular, if the focus is on customer service through interactive communication with customers, the event will become a successful golf equipment exhibition. We consider that the results of 
this study will provide practical implications that can be used as important data to enhance customer relationships in the operation of exhibitions and fairs related to the new products of other companies.

\subsection{Limitations and Future Research Directions}

However, there are some limitations to this study. First, general marketing relationship factors presume that the high purchase intention of consumers affects recommendation intention, but this was not supported in this study, possibly because of the characteristics of the exhibition and fair. In addition, the study only included continuous fair participants/customers, not one-time participants. Therefore, in future studies, it will be meaningful to analyze the relationship between one-time participants and continuous participants. Second, exhibitions and fairs held in Seoul are on a larger scale and include more participants; results in other regions where the scale is smaller may differ from those from large exhibitions and fairs. Thus, in order to host successful small-scale exhibitions and fairs, success factors need to be identified. Third, it may be unreasonable to apply the results to more general consumer products; since this research centered on a golf equipment exhibition and fair, further studies centering on exhibitions and fairs of various products could be of great significance. Fourth, since this study was conducted to analyze the sustainable strategy of a golf equipment exhibition/exposition, it was not possible to investigate the economic aspects of the company, i.e., the measurement of sales or sales volume. Therefore, in future studies, it would be meaningful to conduct an economical study to help an entity's economic performance.

Author Contributions: Data curation, T.C. (Taeyoung Cho); formal analysis, T.C. (Taesoo Cho); methodology and project administration, H.Z.; software, T.C. (Taesoo Cho); writing-original draft T.C. (Taeyoung Cho); writing-review and editing, H.Z. All authors have read and agreed to the published version of the manuscript.

Funding: This research received no external funding.

Institutional Review Board Statement: Not applicable.

Informed Consent Statement: Not applicable.

Data Availability Statement: Not applicable.

Conflicts of Interest: The authors declare no conflict of interest.

\section{References}

1. Kliatchko, J.G. Towards a new definition of integrated marketing communication (IMC). Int. J. Advert. 2005, 24 (Suppl. 1), 7-34. [CrossRef]

2. Kliatchko, J.G. Revisiting the IMC construct. Int. J. Advert. 2008, 27 (Suppl. 1), 133-160. [CrossRef]

3. Madhavaram, S.; Badrinarayanan, V.; McDonald, R.E. Integrated marketing communication (IMC) and brand identity as critical components of brand equity strategy a conceptual framework and research propositions. J. Advert. 2005, 34 (Suppl. 4), 69-80. [CrossRef]

4. Swain, W.N. Perception of IMC after a decade of development: Who's at the wheel, and how can we measure success. J. Advert. Res. 2004, 44, 46-65. [CrossRef]

5. Belch, G.E.; Belch, M.A. Advertising E Promotion: An Integrated Marketing Communications Perspective, 5th ed.; Irwin, Inc.: Huntersville, NC, USA, 2001.

6. Font, X.; McCabe, S. Sustainability and marketing in tourism: Its contexts, paradoxes, approaches, challenges and potential. J. Sustain. Tour. 2017, 25, 869-883. [CrossRef]

7. Cristobal-Fransi, E.; Daries, N.; Ferrer-Rosell, B.; Marine-Roig, E.; Martin-Fuentes, E. Sustainable tourism marketing. Sustainability 2020, 12 (Suppl. 5), 1865. [CrossRef]

8. Moliner, M.Á.; Monferrer, D.; Estrada, M.; Rodríguez, R.M. Environmental sustainability and the hospitality customer experience: A study in tourist accommodation. Sustainability 2019, 11, 5279. [CrossRef]

9. Rosenbaum, M.S.; Massiah, C.A. When customers receive support from other customers: Exploring the influence of intercustomer social support on customer voluntary performance. J. Serv. Res. 2007, 9, 257-270. [CrossRef]

10. Schultz, D.W.; Kitchen, P.J. Integrated marketing communications in U.S. advertising agencies: An exploratory study. J. Advert. Res. 1997, 9/10, 7-18. 
11. Schultz, D.E.; Schultz, H.F. IMC, the Next Generation: Five Steps for Delivering Value and Measuring Financial Returns; McGraw-Hill: New York, NY, USA, 2004.

12. Grove, S.J.; Carlson, L.; Dorsch, M.J. Comparing the application of integrated marketing communication (IMC) in magazine ads across product type and time. J. Advert. 2007, 36 (Suppl. 1), 37-54. [CrossRef]

13. Wilmshurst, J. Below the Line Promotion; Butterworth Heinemann Publication: Oxford, UK, 1993.

14. Cho, T.S. The influence that the quality of information service from golf products suppliers has on customer loyalty: Verifying gender gap with PLS multiple group analysis. J. Sport Leis. Stud. 2014, 58, 175-189. [CrossRef]

15. Wells, W.; Burnett, J.; Moriarty, S.E. Advertising: Principles and Practice; Prentice Hall: Englewood Cliffs, NJ, USA, 2008.

16. Green, C. Communication of service quality in advertising: Are business-to-business ads different? J. Serv. Mark. 1998, 12 (Suppl. 3), 165-176. [CrossRef]

17. Aaker, D.A.; Davis, S.M.; Dunn, M. Building the Brand-Driven Business: Operationalize Your Brand to Drive Profitable Growth; Jossey-Bass: San Francisco, CA, USA, 2002.

18. Kotler, P.; Keller, K.L. A Framework for Marketing Management, 5th ed.; Prentice Hall: Boston, MA, USA, 2012.

19. Schiffman, G.; Kanuk, K. Consumer Behavior; Prentice Hall, Inc.: Englewood Cliff, NJ, USA, 2000.

20. Joyner, L.; Qwynne Lackey, N.; Bricker, K.S. Community Engagement: An Appreciative Inquiry Case Study with Theodore Roosevelt National Park Gateway Communities. Sustainability 2019, 11, 7147. [CrossRef]

21. Daukševičiuté, I.; Valainis, A.; Vilkaitè, N. Conceptualization of the effectiveness of marketing tools. Intelekt. Ekon. 2011, 5, 200-211.

22. Pramanik, R.; Prakash, G. Marketable surplus and marketing efficiency of vegetables in Indore district. J. Agric. Econ. 2010, 7 , 84-93.

23. Reid, M. Performance auditing of integrated marketing communication (IMC) actions and outcomes. J. Advert. 2005, 34 (Suppl. 4), 41-54. [CrossRef]

24. Kotler, P. Marketing Management, 9th ed.; Prentice-Hall Inc.: Englewood Cliff, NJ, USA, 1997.

25. Schmitt, B.H. Experiential Marketing: How to Get Customers to Sense, Feel, Think, Act, Relate to Your Company and Brands; The Free Press: New York, NY, USA, 1999.

26. Brakus, J.J.; Schmitt, B.H.; Zarantonello, L. Brand experience: What is it? How is it? Does it affect loyalty. J. Mark. 2009, 73 (Suppl. 3), 52-68. [CrossRef]

27. Schmitt, B.H. Customer Experience Management: A Revolutionary Approach to Connecting with Your Customers; Wiley: New York, NY, USA, 2003.

28. Ehrenberg, A.S.C.; Barnard, N.; Kennedy, R.; Bloom, H. Brand advertising as creative publicity. J. Advert. Res. 2002, 42, 7-18. [CrossRef]

29. Ganesan, S. Determinants of long-term orientation in buyer-seller relationship. J. Mark. 1994, 58 (Suppl. 4), 1-19. [CrossRef]

30. Shen, D.; Richards, J.; Liu, F. Consumer awareness of sustainable fashion. Mark. Manag. J. 2013, 23, $134-147$.

31. Carrington, M.; Neville, B.; Whitwell, G. Lost in translation: Exploring the ethical consumer intention-Behavior gap. J. Bus. Res. 2014, 67, 2759-2767. [CrossRef]

32. Halbusi, H.A.; Estevez, P.J.; Eleen, T.; Ramayah, T.; Uzir, M.U.H. The roles of the physical environment, social servicescape, co-created value, and customer satisfaction in determining tourists' citizenship behavior: Malaysian cultural and creative industries. Sustainability 2020, 12 (Suppl. 8), 3229. [CrossRef]

33. Magnus, S.; Sara, R. Receiving word-of-mouth from the service customer: An emotion based effectiveness assessment. J. Retail. Consum. Serv. 2007, 14 (Suppl. 2), 123-136.

34. Berry, L.L.; Parasuraman, A. Marketing Service: Competing through Quality; The Free Press: New York, NY, USA, 1991.

35. Kramer, R.M.; Kirby, J.; Bower, J.L.; Rayport, J.F.; Bonabeau, E.; Martin, R.L.; Rosen, J. Breakthrough ideas for 2005. Harv. Bus. Rev. 2005, 83 (Suppl. 2), 17-54.

36. Wilker, L. Travel Industry Prospects Bright Despite Economic Uncertainty: Many Expect to Travel at Least as Much for Holidays and in Coming Year; Deloitte Development: New York, NY, USA, 2007.

37. Sherman, E.; Mathur, A.; Smith, R.B. Store environment and consumer purchase behavior: Mediating role of consumer emotions. Psychol. Mark. 1997, 14 (Suppl. 4), 361-378. [CrossRef]

38. Ming Yeh, T.; Hsing Chen, S.; Fei Chen, T. The relationships among experiential marketing, service innovation, and customer satisfaction: A case study of tourism factories in Taiwan. Sustainability 2019, 11 (Suppl. 4), 1041. [CrossRef]

39. Boulding, W.A.; Staelin, K.R.; Zethaml, V.A.A. dynamic process model of service quality: From expectation to behavioral intentions. J. Mark. Res. 1993, 30 (Suppl. 2), 7-27. [CrossRef]

40. Duncan, T. IMC: Using Advertising \& Promotion to Build Brands; McGraw-Hill: New York, NY, USA, 2002.

41. Kim, J.L.; Cho, T.S. A study on the influence of an early adapter's integrated marketing communication on golf article user's customer orientation and mutual empathy. J. Sport Leis. Stud. 2017, 68, 65-78. [CrossRef]

42. Volos, S. Conceptualizing experience: A tourist based approach. J. Hosp. Leis. Mark. 2009, 18, 111-126. [CrossRef]

43. Lawler, E.J.; Thye, S.R.; Yoon, J. Emotion and group cohesion in productive exchange. Am. J. Sociol. 2000, 106, 616-657. [CrossRef]

44. Kotler, P. Marketing Management; Prentice Hall: Englewood Cliffs, NJ, USA, 2003.

45. Duncan, T.; Moriarty, S.E. Communication based marketing model for managing relationship. J. Mark. 1998, 62 (Suppl. 4), 1-13. [CrossRef] 
46. Keller, K.L. Strategic Brand Management and Best Practice in Branding Cases, 2nd ed.; Prentice-Hall: Englewood Cliffs, NJ, USA, 2003.

47. Bagozzi, R.; Yi, Y. On the evaluation of structural equation models. J. Acad. Mark. Sci. 1988, 16 (Suppl. 1), 74-94. [CrossRef]

48. Cohen, J.; Cohen, P. Applied Multiple Regression/Correlation Analysis for the Behavioral Sciences; Erlbaum: Hillsdale, NJ, USA, 1983.

49. Hair, J.F., Jr.; Anderson, R.E.; Tatham, R.L.; Black, W.C. Multivariate Data Analysis with Reading, 5th ed.; Prentice-Hall. Inc.: Englewood Cliffs, NJ, USA, 1998.

50. McGrath, J.M. Integrated Marketing Communications: An Empirical Test of Its Effectiveness. Ph.D. Thesis, The Graduate School College of Communication, The Pennsylvania State University, State College, PA, USA, 2001.

51. Krizanova, A.; Lăzăroiu, G.; Gajanova, L.; Kliestikova, J.; Nadanyiova, M.; Moravcikova, D. The Effectiveness of Marketing Communication and Importance of Its Evaluation in an Online Environment. Sustainability 2019, 11 (Suppl. 24), 7016. [CrossRef]

52. Luck, E.; Moffait, J. IMC: Anything really changed? A new perspective on an old definition. J. Mark. Commun. 2009, 15 (Suppl. 5), 311-325.

53. Mulhern, F. Integrated marketing communications: From media channels to digital connectivity. J. Mark. Commun. 2009, 15 (Suppl. 2-3), 85-101. [CrossRef]

54. Peltier, J.W.; Schibrowsky, J.A.; Schultz, D.E. Interactive integrated marketing communication: Combining the power of IMC, the new media and database marketing. Int. J. Advert. 2003, 22 (Suppl. 1), 93-115. [CrossRef]

55. Shimp, T.A. Integrated Marketing Promotions in Advertising and Promotion, 7th ed.; South-Western, Thomson Learning: Mason, OH, USA, 2007.

56. Ladhari, R. Assessment of the psychometric properties of SERVQUAL in the Canadian banking industry. J. Financ. Serv. Mark. 2009, 14 (Suppl. 1), 70-82. [CrossRef]

57. Jaiswal, A.K.; Niraj, R. Examining mediating role of attitudinal loyalty and nonlinear effects in satisfaction behavioral intentions relationship. J. Serv. Mark. 2011, 25 (Suppl. 3), 165-175. [CrossRef]

58. Schultz, D.E. The evolving nature of integrated communications. J. Integr. Commun. 1997, 8, 11-18.

59. Schultz, D.E. Integrated marketing communications and how it relates to traditional media advertising. In The Advertising Business: Operations, Creativity, Media Planning, Integrated Communications; Jones, J.P., Ed.; Sage: London, UK, 1999. 